\title{
Access and allocation in global biodiversity governance: a review
}

\author{
Brendan Coolsaet $^{1,2} \mathbb{D} \cdot$ Neil Dawson $^{1,2,3} \cdot$ Florian Rabitz $^{4}\left(\mathbb{D} \cdot\right.$ Simone Lovera $^{5}$
}

Accepted: 3 April 2020 / Published online: 17 April 2020

(c) The Author(s) 2020

\begin{abstract}
Access and allocation is one of the five analytical themes of the science plan of the Earth System Governance (ESG) project. Concerns over access and allocation are at the core of struggles and conflicts brought about by the often ineluctable trade-offs related to biodiversity conservation and the global, national and local governance systems that aim to contribute to global biodiversity conservation. Access and benefit-sharing mechanisms, integrated conservation and development projects, payments for ecosystem services or community conservation programmes have all tried balancing environmental objectives with concerns for the allocation of natural resources and associated rights within society, and for access to basic human needs. As a contribution to this special issue on access and allocation, this paper aims to contribute to the analysis of the relevance of questions of access and allocation to ESG by providing an in-depth review of the literature on access and allocation in biodiversity conservation at different scales. We describe how the concepts of access and allocation have been used and conceptualized in the literature produced between 2008 and 2018, and we discuss the two key issues which dominate the literature (1) benefit-sharing; and (2) the role of local institutions. By drawing on the trends and evidence from the literature, we consider the lessons for the next generation of ESG scholars and draw out some key policy implications to be included in the debates on the post-2020 strategic plan for biodiversity.
\end{abstract}

Keywords Access · Allocation · Biodiversity $\cdot$ Conservation $\cdot$ Benefit-sharing $\cdot$ Justice

Electronic supplementary material The online version of this article (https://doi.org/10.1007/s 1078 4-020-09476-6) contains supplementary material, which is available to authorized users.

Brendan Coolsaet

brendan.coolsaet@univ-catholille.fr

1 European School of Political and Social Sciences (ESPOL), Lille Catholic University, Lille, France

2 Global Environmental Justice Research Group, School of International Development, University of East Anglia, Norwich, UK

3 Centre for the Synthesis and Analysis of Biodiversity (CESAB), French Foundation for Research on Biodiversity (FRB), Montpellier, France

4 Research Group Civil Society and Sustainability, Kaunas University of Technology, Kaunas, LT, USA

5 Global Forest Coalition, Asunción, Paraguay 


\section{Introduction}

This paper focuses on concerns over access and allocation which are at the core of struggles and conflicts brought about by the often ineluctable trade-offs related to the conservation of global biodiversity (Robinson 2011). These issues have gained importance since the 1980s, with the emergence of 'new conservation' (Miller et al. 2011), the 'sustainable use' paradigm (Broggiato et al. 2015) and so-called 'rights-based conservation approaches' (Kashwan 2013) at local, national and international levels, gradually replacing the traditional 'fences and fines' approach. Access and benefit-sharing mechanisms, integrated conservation and development projects, payments for ecosystem services or communitybased programmes have all tried balancing environmental objectives with concerns for the allocation of natural resources and associated rights, and for ensuring access to the basic human needs of affected populations in the context of biodiversity conservation.

These approaches have in common the assumption that ensuring access to livelihood resources and allocating benefits flowing from conservation interventions with local communities will deliver both economic development and create long-term incentives for conservation. Yet, while global conservation goals have adopted increasing social dimensions, the conservation sector comprises states, donors and NGOs with control over considerable resources employing well-established practices and narratives at a global scale, which may conceivably obstruct transformations and local aspirations in practice. Inconsistencies and tensions between governance systems across different scales and levels raise additional challenges for ensuring that access and allocation is both equitable and effective. It is therefore important to understand how access and allocation is being organized in practice.

This paper provides an in-depth review of the literature produced between 2008 and 2018 on access and allocation in biodiversity governance. Following a conceptual introduction on access and allocation in Earth System Governance (ESG) (Sect. 2) and an overview of the used methods (Sect. 3), we describe how the concepts of access and allocation have been used and conceptualized in the literature on biodiversity governance and conservation (Sect. 4), focusing on what, where, how and by whom access and allocation is being organized, managed and controlled. In Sect. 5, we explore the two key issues which dominate the literature (1) benefit-sharing; and (2) local institutions. In Sect. 6, we look at some of the evidence on the links between access and allocation, and the effectiveness of governance in meeting conservation goals. Based on this, we consider the lessons for the next generation of ESG scholars and draw out some key policy implications to be included in the debates on the post-2020 global biodiversity framework.

\section{Access and allocation in Earth System Governance}

According to the ESG project, access is about 'meeting the basic needs of humans to live a life in dignity', while allocation is about the distribution of 'benefits, responsibilities, and involuntary risks between countries and actors' (Biermann et al. 2009: 60). The ESG science plan also explicitly emphasizes access and allocation to be related to 'justice, fairness, and equity' (Biermann et al. 2009: 60).

Drawing on this, Gupta and Lebel (2010) understand access and allocation as 'the ability of individuals to secure a basic minimum of resources and ecospace' as well as the distribution of resources, risks, burdens and responsibilities for environmental challenges. 
By focusing on ability, Gupta and Lebel seem to be building upon Ribot and Peluso's seminal work, A Theory of Access (2003), even though the latter is never exploited. Ribot and Peluso define access as 'the ability to derive benefits from things' (2003: 153). Responding to common property scholarship (e.g. Schlager and Ostrom 1992), they differentiate their approach by stressing the importance of power relations in understanding why some people enjoy access to natural resources and benefit from them, 'whether or not they have rights to them' (2003: 154).

While having different foci, the distinction between access and allocation is not clear-cut and the terms are often used as synonyms. For instance, rights (such as land rights) can be both accessed and allocated. The use of natural resources (such as forest products) may also be understood as falling into either category. Understood in a narrow sense, allocation thus refers to the (re-)distribution of resources after initial access has taken place. The utilization of natural resources involves an instance of access being logically prior to the subsequent allocation of resulting monetary and non-monetary benefits, for example.

Regarding biodiversity, access and allocation involves a broad range of issues. Payments for ecosystem services involve restrictions on access to natural resources while also raising questions regarding the distribution of financial flows among local stakeholders. Similar access restrictions may result from protected areas. Ecotourism may impact the availability, as well as access to, natural resources but also imply the generation of benefits to be distributed. Discussions of access and allocation are thus not limited to the question of 'Who gets what, when, where and how?'. Rather, a key theme in the literature is how processes related to access and allocation, from local to global scales and through various political mechanisms, impact the natural environment and social wellbeing.

\section{Method}

A systematic review was used to probe the literature on access and allocation, following a three-step method. The first step involved a comprehensive search of Web of Science articles (SSCI Index) and using keywords related to both access and allocation, and biodiversity. The conceptual framework outlined above was used to identify proxies to ensure completeness of the review, as access and allocation are not necessarily explicitly referred to in the literature (see supplementary material). For example, it is common for authors to refer to benefit-sharing and inclusion in decision-making without making explicit references to the issues of access and allocation. This first literature search yielded a first batch of 488 papers.

The second step involved the screening of the titles, abstracts and, if needed, the content of the 488 papers against the following inclusion criteria: (1) addresses an issue of access and allocation, (2) deals with biodiversity conservation broadly understood, and (3) published between 2008 and 2018. 147 studies were identified as meeting the different criteria on access and allocation in over 45 countries. (The list of papers is available in the supplementary material). Most excluded studies did not address the issue of access and/or allocation as defined above, but were just using the terms. Other studies were excluded because they were not directly related to biodiversity; for example, studies focussing on (access and allocation of) land tenure and/or land rights without including a specific biodiversity angle. A small subset of studies was excluded because it did not meet the quality standards.

In the third step, all studies were carefully read to ensure attention to access and allocation was noted and corresponded to the conceptual framework outlined above. Data 
from the studies was extracted and coded in a codebook, including the following primary categories: (1) bibliography; (2) methodology; (3) type of biodiversity considered (e.g. forests, ecosystem services, land, marine area, etc.); (4) concepts used for access and allocation (e.g. terms and definitions used by the author, what is being accessed/ allocated?, etc.); (5) subjects of access and allocation (access/allocation for whom?); (6) governance mechanisms for access and allocation (who provides access/allocation?, what mechanisms are used?, at what scales?); and (7) outcomes of access and allocation interventions. The outcomes were disaggregated with secondary subcomponents of observed positive outcomes, negative outcomes and specific impacts according to gender, race or class, when available.

\section{How have access and allocation been used and conceptualized in relation to biodiversity governance?}

\subsection{Terms used for access and allocation}

At first glance, hardly any of the papers of our review incorporate the terminology of 'access and allocation' as understood in the ESG project, suggesting a limited influence of ESG terminology on the broader literature. Rather, access (to something) is most often used as a stand-alone term, or specifically related to rights ('access rights'), while (re)allocation (of something) is largely underrepresented in the literature. However, more commonly used terms used for access and allocation in the literature ('benefitsharing' or simply 'benefits', '(re)distribution' of something and 'equity' or 'equitable') point at a rather distributive understanding of access and allocation, which aligns with

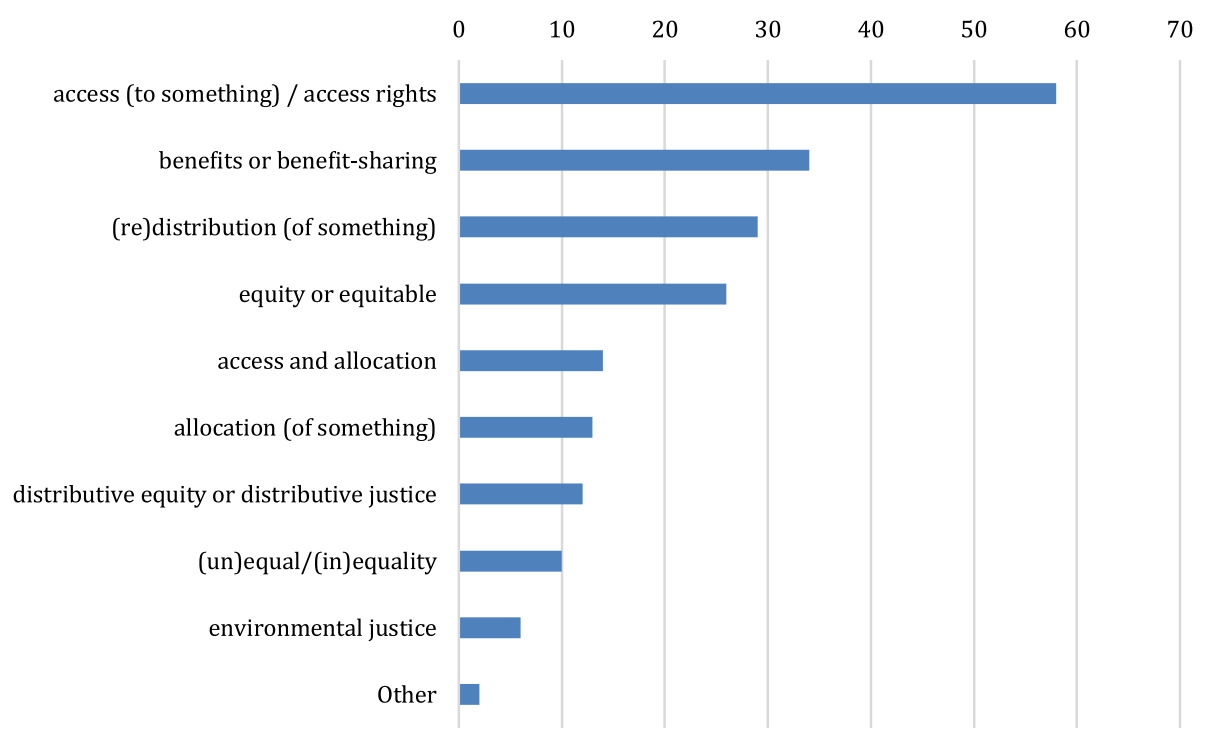

Fig. 1 Terms used for access and allocation 
the original ESG science plan (Biermann et al. 2009). Other terms include justicerelated wording such as environmental, distributive or procedural justice and equity, fairness and (in)equality (see Fig. 1).

In our subset of papers, no definitions of 'allocation' are given, and only a handful of papers define access, often referring to Ribot and Peluso's definition (2003). Even when not explicitly drawing on this definition, most authors of our studies seem to have a similar understanding of access. At the same time, as indicated above, access is often associated specifically with rights (e.g. 'access rights'). While some also take over Ribot and Peluso's distinction between access and property, other authors seem to merge both approaches. Asiyanbi (2016: 151), for example, states that 'access is understood as the most basic of the bundle of rights in a resource, which is the right to benefit from the resource' (emphasis added). Finally, as discussed further below, and unlike in the conceptual definitions of the term, access is largely approached in a negative and restrictive way. Hochleithner (2017), for example, argues that nature conservation based on different forms of enclosures can be understood as gaining control over customary ways in which access is being organized and benefited from.

\subsection{Geographic distribution and biodiversity categories}

As global biodiversity is unequally distributed across the globe, studies regarding issues of access and allocation of biodiversity unsurprisingly occur primarily in the Global South, with approximately 51, 29 and 43 studies in Africa, Latin America and the Caribbean and Asia, respectively. (Thirty studies did not define a specific geographic location.) Strongly represented countries in our subset include Indonesia, Tanzania, Brazil, Mexico, Vietnam and India.

The studies in our review are concerned primarily with forests and different forms of protected areas (PA). Ecosystem services, land, wildlife and other categories (e.g. wetlands, agricultural biodiversity, genetic resources, landscapes and marine areas) are represented too, albeit in much smaller numbers (see Fig. 2).

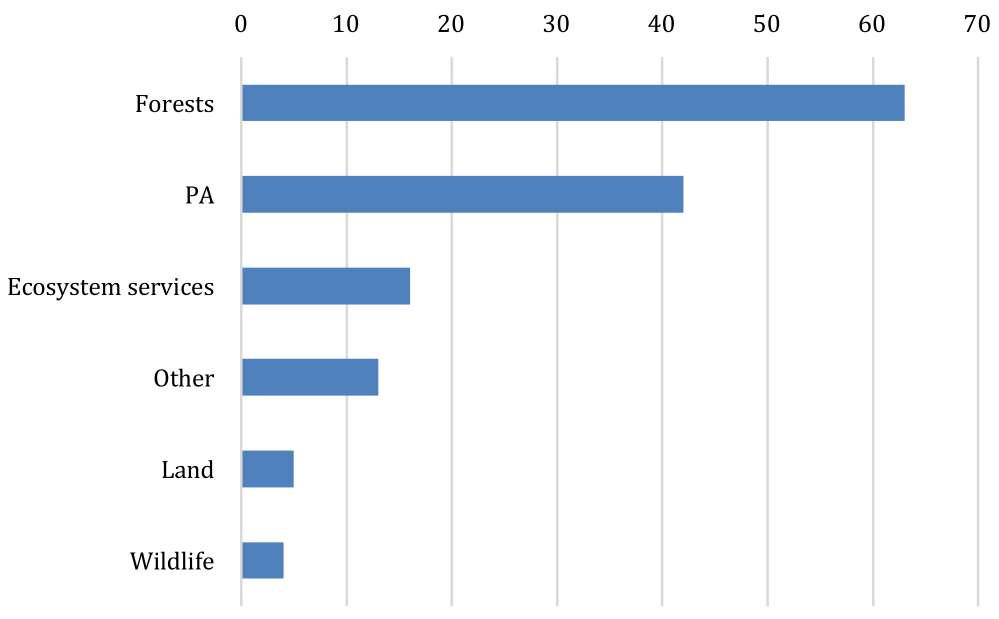

Fig. 2 Biodiversity categories 


\subsection{What is being accessed and/or allocated?}

As the ESG science plan notes, 'problems of access differ from issue to issue' (Biermann et al. 2009). How, then, has access and allocation been attempted in the context of biodiversity conservation? What specific kind of resources and rights are being accessed and allocated in order to ensure the ability of individuals to secure basic human needs?

As discussed earlier, the language of access and allocation is often associated with rights-based language, including references to tenure and property rights, and rights to exploit or otherwise benefit from natural resources. The latter include collection rights, logging permits and other forest harvesting rights, production quotas and hunting blocks. Barsimantov et al. (2011) distinguish different tenure bundles in this respect, including withdrawal rights, management rights, exclusion rights and alienation rights. Different forms of payments for ecosystem services (e.g. forest and carbon benefits), as well as tourism revenue shares and agricultural returns, were also allocated. Payments for ecosystem services, financial compensation for wildlife-induced property loss, budget or other financial resources and, for example, management power or decision-making influence were allocated as well. In one case, the ability to utilize indigenous knowledge was allocated.

The terms access and allocation are also often found to be used in relation to social services like education, health, sanitation or electricity, or to a wide range of economic assets (i.e. Faye and Ribot 2017; Ingram 2017; Tysiachniouk and McDermott 2016). The latter includes financial, human, physical and social capital. For example, it includes funds, credits, loans, income, remittances, inputs and permits, as well as (urban) markets and jobs (i.e. Ball and Brancalion 2016; Gupta 2015). It also includes access to, or allocation of, less material livelihood resources such as labour, training, knowledge, information, social networks, justice and mobility (i.e. Parker et al. 2015).

Several authors indicate that such access to, or allocation of, non-biodiversity-related assets plays an important role in community conservation initiatives and the interaction between biodiversity conservation and community livelihoods in general. Ball and Brancalion (2016), for example, indicate that access to non-timber forest products only provides more economic opportunities for women if they have access to markets and resources as well.

Last but not least, an important point of difference in the academic conceptualization of the social dimensions of biodiversity conservation is the extent to which participation and recognition of local communities and indigenous peoples are considered a part of access and allocation. The sample of reviewed papers could be split roughly in two: twothirds focus mainly on the material dimensions of local communities' well-being (through income, employment or access to basic needs) with little to no consideration of participation (or only cursory attention to recording if local people participate in meetings about conservation) or recognition of subjective values and practices. The last third includes attention to the nature and quality of participation, influence in governance in addition to exploring local values, identities, plurality of knowledge and the impacts of including or excluding local institutions and social and cultural practices.

\subsection{Actors and governance of access and allocation}

Exploring the main actors and the governance mechanisms driving access and allocation helps us understand the extent to which policy and regulatory instruments at local, national 
and international scale continue to modify and allow (or deny) access to resources and rights. As Ribot and Peluso (2003) note, 'some people and institutions control resource access, while others must maintain their access through those who have control'.

In most studies covered in this review, the power to modify and control access and allocation of resources and rights lies with non-local actors such as park authorities, national or international tour operators and hoteliers, regional or national governments, ministries and parastatal bodies, NGOs or 'the market'. Only occasionally are access and allocation reported to be controlled by local decision-making bodies, such as traditional councils, community-based associations or farmers cooperatives, some of which are made possible through state-centred initiatives and legal frameworks protecting the right to self-determination (e.g. He and Sikor 2015; Pasgaard 2013). In contrast to who controls governance, the subjects of access and allocation are for the most part local stakeholders and their communities, sometimes disaggregated by income, gender or ethnicity and race.

While actors and subjects of access and allocations seem to be distributed along a nonlocal/local dichotomy, giving the impression of access and allocation introduced and controlled from outside, the governance arrangements in our studies tend to blur this line. While the traditional instruments are well-represented-state-led protected areas with more or less top-down access restriction, and market-based instruments such as PES and offset programmes - decentralized approaches are also commonly reported in our studies, including customary systems, co-ownership programmes, community-based resource management schemes and more informal traditional institutions in which local and non-local actors share power (e.g. Berbés-Blázquez et al. 2017; Montoya and Young 2013). However, while these deliberative, multi-scale governance platforms can help elicit common ground and identify shared values and objectives, the literature illustrates how the functioning of power to determine rules and to influence outcomes is not so easily transformed. Local governance itself does not automatically trigger benefits for people and biodiversity, even though local actors have a number of incentives to strive for long-term benefits for local people and thus for forms of natural resource exploitation that facilitate long-term biodiversity conservation. But the papers reviewed show that gender, ethnic and other inequities may persist within local governance structures, and local governance structures are not always able to ensure long-term sustainable use. Moreover, institutional relationships across scales and sectors, through national and international political structures and discourses may still dominate. For example, several papers described how control over access and allocation, though formally decided by local actors through co-management schemes, rested with forest services or other governmental actors which strongly influenced such local decision-making, often to the detriment of community interests (e.g. Sowman and Sunde 2018; Parker et al. 2015).

\section{Key issues regarding access and allocation in relation to biodiversity governance}

\subsection{The failed promise of benefit-sharing}

From our review, benefit-sharing mechanisms clearly appear to be the preferred tool to address issues of access and allocation in biodiversity conservation. This is not surprising, given the distributive leaning of the ideas of access and allocation in both conceptual discussions and in empirical observations, as indicated above. 
While the nature and the sources of these benefits can vary widely, as described earlier, the supporters of such mechanisms hope they can increase the income of local communities and hence contribute to both development and conservation efforts. The narrative behind this popular approach is that for "the hoped-for "win-win" scenario to work in practice, individuals and households must receive benefits which compensate them for the costs of conservation which they suffer' (Sandbrook and Adams 2012: 14).

The problem, however, is that access and allocation, when conceived only as benefitsharing, may overlook the capability of local communities to actually benefit in the long run. Moreover, as Schroeder notes, benefit-sharing programmes 'have often failed altogether to come to grips with the underlying demands for fair compensation and fundamental social, political, and economic changes those rural groups articulate' (Schroeder 2008).

Indeed, as documented throughout the papers in this review, benefit-sharing arrangements are prone to a multitude of problems when implemented, including elite capture (Lammers et al. 2017; Moyo et al. 2017), disempowerment (e.g. Mbaiwa et al. 2011), dispossession of natural resources (Moscoe and Emshwiller 2016; Suiseeya 2014), and exacerbation of poverty (Pelletier et al. 2018). In some cases, unequal outcomes result from the interaction of new governance arrangements with existing social inequalities (TorpeySaboe et al. 2015). In other cases, such outcomes are a direct consequence of flawed institutional design (Lammers et al. 2017).

In part, this is due to the colonial experience in spaces where most of our studies are conducted. A long history of weakening traditional institutions has allowed elites to use economic incentives as leverage and control mechanisms, rather than as capital serving to improve access to natural resources and the allocation of rights. Several authors highlight that processes driving inequality are historically rooted, resulting in a lack of capacity, access or agency among certain groups and require specific attention to avoid reproducing similar injustices through conservation efforts (Adhikari et al. 2014; Torpey-Saboe et al. 2015; Tysiachniouk and McDermott 2016; Thorkildsen 2016; Pasgaard 2013). These historical inequalities and injustices frustrated the effect of governance arrangements that attempted to increase access and allocation to resources for local communities. Chomba et al. (2015), for example, show how the socio-economic differentiation caused by colonial land allocations leads to persisting inequalities in accessing forest benefits, such as water, with large landholders benefitting disproportionately from community-based forest management.

This risk of elite capture appears to be independent from the source of the benefits to be accessed and allocated, including traditional nature conservation projects (see e.g. Lammers et al. 2017; Schroeder 2008); wildlife management (Moyo et al. 2017); protected areas (Clifton 2013; de Araujo et al. 2017; Horton 2009) and payment for ecosystem services (PES). On the latter, Hendrickson and Corbera (2015) find that political inequalities are so deeply engrained in most Mesoamerican societies that PES schemes are likely to reinforce the existing power structures and deepen existing inequalities in both decisionmaking and in gaining access to resources. Pelletier et al. (2018) reveal the predictable inequity of social impacts through a REDD+ pilot project in the Democratic Republic of Congo, and Andersson et al. (2018), in a cross-national analysis, show how REDD+ funding can exacerbate wealth inequalities. The disproportionate consequences for the poorest of access restrictions are also central for the analysis of biodiversity offsetting projects in Madagascar by Bidaud et al. (2018).

When not subsidized by external actors, benefit-sharing often involves local commercial activities such as ecotourism and hunting. As with benefit-sharing, the assessment of ecotourism in the literature emphasizes the co-existence of both positive and negative 
environmental and socio-economic outcomes. One of the few papers on access and allocation in industrialized countries highlights how commercial hunting tourism undermines local practices in Norway (Øian and Skogen 2016). Hunt et al. (2015) show how ecotourism in the Osa peninsula, Costa Rica, overall implies positive social welfare effects. Tourism in a Ugandan national park provides widely accessible benefits to almost everybody living in the study area, although the ability of locals to maintain and control access to benefits from tourism revenue sharing remains limited (Sandbrook and Adams 2012). Tourism revenue sharing under the Zimbabwean Communal Areas Management Programme for Indigenous Resources improved conservation incentives and led to a decrease in poaching (Fischer et al. 2011). Ecotourism in Ghana similarly led to an increased availability of benefits for local communities while, in some instances, restricting access to natural resources (Appiah-Opoku 2011). In La Fortuna, Costa Rica, ecotourism improved social, economic and environmental sustainability as well as the distribution of economic benefits among local communities (Matarrita-Cascante et al. 2010). Horton (2009) comes to similar conclusions for Costa Rica, while also highlighting the risks of elite capture and land price increases.

Few papers reach the conclusion that alternative benefit-sharing and compensation initiatives reduce resource dependency, but most suggest that social and political complexities (corruption, poverty, challenges for full and effective participation) must be taken into consideration to prevent benefits accruing to those least in need of it. Disregard to sociocultural context in the design of allocation mechanisms may lower the quality of environmental outcomes (He and $\mathrm{Xu}$ 2017; Moyo et al. 2017). There is thus a broad consensus in the literature regarding the need for appropriate fit between mechanisms for access and allocation, and local institutions.

\subsection{The role of local institutions}

Studies including the role of local institutions in the conservation of biodiversity are arguably more able to capture, and less likely to overlook, local priorities and experiences, such as the way people's well-being may be connected to nature, materially and culturally, through places, species, resources and processes.

In terms of biodiversity governance, this distinction is important because the types of conservation interventions that have become mainstream policy responses, from protected areas to biodiversity offsets and payments for environmental services, commonly comprise externally driven initiatives that regulate access and allocation for local communities and indigenous peoples. They are often seen as 'parachuted, fully formed into society and literally imposed by the government on the people' (Mordi 1991, cited in Mbaiwa et al. 2011), and afford locals very limited power and their institutions little role while promoting alternative livelihoods to reduce land and resource use. For example, if the social impact and degree of success of an intervention is assessed based on changes in income, housing standards or employment, rather than the extent to which the intervention supports local governance institutions, it may be assumed that access restrictions imposed through conservation interventions are locally acceptable and can be materially compensated quite easily.

However, studies taking a more nuanced approach to social diversity and inclusion have also evidenced the impacts of conservation governance as frequently implying exclusion, dispossession and violations of rights, leading to lack of local support, resistance and 
arguably limited success in conserving nature (e.g. Gustavsson et al. 2014; Kopnina 2016; Moyo et al. 2017; Lammers et al. 2017; Bidaud et al. 2018).

Studies from our sample covering participation and recognition revealed a number of important findings. Although formally recognized access or legal property rights generally strengthen the participation of, and outcomes experienced, by local actors, it is communal rights, particularly communal and customary land tenure that (where national policies are supportive) tend to provide more inclusive forms of participation with outcomes favouring a wider range of community members (Saito-Jensen et al. 2015; Pinyopusarerk and Tran 2014). Several papers described a façade of participation, where access and allocation appears to be formally determined by local actors like community leaders within 'community-based' resource management. Yet, because power was not effectively transferred to them and governmental actors maintained ultimate control, community interests were sidelined (e.g. Faye and Ribot 2017; Faye 2017; Bluwstein et al. 2016). In cases where wider economic forces are allowed to determine access, redistribution occurred towards more powerful actors while local community access to land and other natural resources tended to decrease, with negative impacts particularly on the livelihoods of the most marginalized households within the community (e.g. Øian and Skogen 2016; Orchard et al., 2016).

Cumulatively, this evidence suggests that to achieve equitable social outcomes requires local institutions to be respected and included within conservation governance, if not on their own then combined through a form of 'institutional bricolage' (Cleaver et al. 2013). However, local institutions are often complex, undocumented and some, for example, customary tenure systems, may operate in contradiction of formal national land laws, and require specific efforts to enhance their legitimacy as part of a local conservation initiative. Also, local institutions do not always address potential gender or ethnic inequities in power relations and access and allocation arrangements within communities. They also are not a guarantee for long-term sustainable use of biodiversity, as certain economic, cultural or social incentives might trigger overexploitation by some or all local actors. Incorporating local institutions requires continual negotiation alongside efforts to build capacity, trust, communication and collaboration (Cleaver et al. 2013; Ingram et al. 2015). It is therefore paramount that studies of biodiversity governance adopt a nuanced approach to the procedures and aspects of power and participation that determine who, and through what types of interactions, are able to control and influence the design of governance and outcomes experienced.

\section{Outcomes of access and allocation interventions}

Evidence of the social and ecological results of access and allocation arrangements is mixed at best and commonly negative. Suma and Großmann (2017), for instance, show how initiatives for promoting sustainable development, social well-being and gender equality in Kerala, India, have partially worsened women's access to land and seeds. Programmes based on a logic of conserving biodiversity through decoupling local people from particular places, resources uses and practices tend to have particularly prominent impacts. Asiyanbi (2016) highlights how the introduction of a REDD+ scheme in Nigeria has led to negative consequences for local livelihoods through restrictions of access to timber and non-timber forest products for local communities. Such impacts need not be limited to distributional outcomes. Sowman and Sunde (2018) argue that the creation of marine protected areas in South Africa weakens local governance arrangements and local stakeholder 
participation. Notably, although each of these findings have implications for gender, class and ethnic distinctions, relatively few studies explicitly mention equity issues related to differentiated access or allocation between women and men (7) or ethnic groups (5).

Many authors place great emphasis on the ways in which local property regimes, and externally induced changes thereto, impact on biodiversity conservation and use. A range of authors in our sample consider collective property rights of local communities as more effective in ensuring conservation and sustainable use than private or state property rights. For instance, Adhikari et al. (2014) argue that the transfer of property rights to disadvantaged members of local communities can enhance their effective participation in collective resource governance. Roy et al. (2013) hold that the displacement of state property regimes with community-based ownership could lead to improved conservation outcomes. Bottazzi and Dao (2013) find that for the case of Andean settlements, collective property rights over land are associated with lower degrees of deforestation compared to areas in which individual property rights apply. A rare exception is Kubitza et al.'s (2018) analysis of land property rights in Indonesia, where the authors conclude that strong individual land titles contribute to agricultural intensification and thus reduce incentives for deforestation. Beyond the general slant towards collective property rights in the literature, some authors argue that weak or unclear rights may lead to unsustainable resource usage (Bartkowski et al. 2018) or undermine the effectiveness of market-based instruments in resource management (Lockie 2013). In Ghana, unclear property rights over land dating back to the colonial era constitute barriers to distributional equity (Saeed et al. 2018).

However, some authors argue that conservation measures either do not have tangible impacts on access and allocation by local stakeholders, or may even promote participation and equity. Chechina et al. (2018) show that the implementation of forest conservation measures in the Philippines is unlikely to decrease socio-economic well-being. Vorlaufer et al.'s study on payments for ecosystem services in Indonesia similarly argues that conservation measures may be deliberately designed for channelling financial benefits to low-income stakeholders. Overall, it appears that the social and environmental consequences for access and allocation of measures for biodiversity conservation and sustainable use depend on local conditions (including informal rules and procedures as well as socioeconomic power structures), institutional design, and contextual, often historically rooted, inequities.

Although local institutions regulating access and allocation may have existed for long timescales, their capacity for effective biodiversity governance is often underestimated and unsupported. As a result, interventions that seek explicitly to empower local communities and their own institutions to play a lead role in governance and act as custodians of biodiversity, are far from mainstream practice (Cardona et al. 2014), and quite uncommon among REDD, PES, biodiversity offset initiatives or strict protected areas. Some authors argue that deliberative, multi-stakeholder platforms can elicit common ground, shared values and mutually agreed objectives. Such negotiation of interests can enable desirable outcomes (and pathways to achieve them) to become explicit rather than assumed, and allow objectives and modes of governance to be co-produced rather than predetermined or imposed (Torpey-Saboe et al. 2015; van Wyk et al. 2014; Pinyopusarerk and Tran 2014). Local institutions may be more geared, aware of and responsive to social context, such as particular inter-group sensitivities/relations based on past political events (Cleaver et al. 2013; Clifton 2013). They can also be more responsive to external drivers such as new commodity frontiers emerging, which may alter economic incentives associated with different land uses and undermine simple, compensation-based conservation schemes (Martin et al. 2013; Montoya and Young (2013); Bottazzi and Dao 2013). 


\section{Discussion and conclusion}

While there is evidence that access and allocation mechanisms can enhance the quality of biodiversity conservation and improve social well-being, our review shows that the quality of outcomes is strongly dependant on the political economy in which they take place, on the nature of the process leading to them, and on the underlying social and ecological objectives they pursue.

Interventions aiming to conserve biodiversity produce social as well as ecological outcomes, which do not occur independently and are linked through intricate pathways. The well-being of local and indigenous communities is often highly interlinked with ecosystems and the places and resources they hold, in multiple, complex and changing ways that go far beyond basic needs. It is surprising then that conservation and development are often discussed as separate issues to be performed by different organizations, or even comprise efforts to decouple local livelihoods from nature. This methodological division is far from trivial or a case of academic hair splitting, but rather is tied to a key ideological rift in the logic supporting conservation and development interventions and how associated governance is formulated.

It is striking to see how similar the reported shortcomings are across the different studies in our review. Often this has arisen from a focus on the conditions of access (and allocation to a lesser extent) rather than on the constraints, interests and opportunities for access and allocation. Contemporary studies of ESG, irrespective of scale, should not simply follow the logic associated with an intervention, but explore the multiple social dimensions to assess governance features and impacts from multiple perspectives and identify innovative processes, pathways and transformations through which social and ecological objectives may best be pursued in different contexts. These social dimensions shape the extent to which access and allocation work for biodiversity conservation.

Specific, innovative examples among the sample studies include progressive shifts in protected area governance towards community-based resource management through negotiated agreements relating to habitats and resources. The innovations in governance can be characterized as a form of institutional bricolage that can lead to more favourable and equitable outcomes for local communities and minority groups among them. The complex ways in which resources are accessed by different members of communities make it very unlikely that externally controlled benefit-sharing mechanisms based on market-led or colonial structures can foster such transformation. Such innovation necessitates willingness of those in control, whether state agencies or NGOs, to cede power in the hope of achieving enhanced, transformative outcomes that may result in less conflict, more cooperation and greater possibilities of realizing ecological and social synergies.

The two key themes identified in this review, the low efficacy of access and allocation mechanisms for delivering tangible benefits to vulnerable socio-economic groups, including women and ethnic minorities, as well as the need to adapt such mechanisms to pre-existing local institutions, also have important implications for international biodiversity governance. Under the Convention on Biological Diversity (CBD), parties and other stakeholders are presently negotiating a post-2020 global biodiversity framework that will guide future efforts at ensuring conservation, sustainable use as well as fair and equitable benefit-sharing.

However, the draft version of the framework available at the time of writing (CBD 2020) includes few targets that relate to benefits for vulnerable groups: improved nutrition, enhanced availability of freshwater resources, as well as the 'full and effective 
participation' in biodiversity-related decision-making by indigenous peoples, local communities, women and youth. While the papers we reviewed are broadly supportive of stronger community governance over biodiversity, including through legal access and allocation arrangements that strengthen local governance rights, the draft framework pays too little attention to the impacts of governance arrangements on access and allocation by local communities. This disregard to local institutional settings possibly limits the effectiveness of biodiversity governance mechanisms folded into the post2020 framework. This might directly affect the ability to deliver effective solutions for biodiversity conservation and sustainable use through issue linkage to socio-economic development.

Besides the generic institutional functions which an effective post-2020 framework would need to provide, such as coordination, the monitoring of collective progress or incentives for increasing compliance, a number of specific design features related to our overall findings stand out. Firstly, it is essential for the overall effectiveness and equity of the post-2020 GBF that the specific targets that have been proposed in February 2020 to address multi-scale, gender-responsive biodiversity governance and more equitable access and allocation arrangements, including through the recognition of local land tenure rights, are incorporated. Second, enhancing the effectiveness and equity of governance mechanisms for access and allocation of biodiversity requires systems for monitoring and evaluation, based on performance indicators that include socio-economic variables, and a global scientific assessment processes that properly address benefit sharing, access and allocation and other social and economic dimensions of biodiversity governance, and that feeds into periodic reviews under the CBD's Conference of the Parties (see e.g. Zafra-Calvo et al. 2017). Third, implementation mechanisms, including funding mechanisms, should focus more strongly on the equity dimensions of biodiversity governance, and related access and allocation arrangements.

While not inevitable, more systematically taking into account local institutions may generate trade-offs. The papers in our review highlight some of the complex social and political factors to address if these trade-offs are to be avoided, including differentiated access, overlapping tenure rights, historic dispossession or conflict, lack of transparency, unsupportiveness of national and regional policy regimes, vested power, volatility of global commodity prices that compensation schemes cannot compete with, financial dependencies or other perverse incentives, contextual inequities and more practical obstacles to equal participation, like language, cultural and gender barriers.

Alongside a progression in wider policy norms, addressing these different factors requires scholars to more thoroughly consider concerns for justice and power in conservation policy. Despite its varied interpretations, references to justice and power remained rather scarce in the specific framing of 'access and allocation' of the initial ESG science plan (Biermann et al. 2009). By failing to engage more broadly with either environmental justice or resource politics scholarship, the original ESG science plan perhaps tried redefining concepts that already had widely accepted meaning elsewhere. As a result, justice and power concerns regarding 'access and allocation' in biodiversity and natural resources governance have largely been taken up in other emerging research since the early 2000s [for an overview on justice see Martin (2017); on power see Myers and Hansen (2020)]. We find hope in the fact that the groundwork has been laid for this shortcoming to be addressed by the next generation of ESG scholars (see Earth System Governance Project 2018).

Acknowledgements $\mathrm{BC}$ and ND have benefited from preparatory work for the 'JustConservation' research group funded by the Centre for the Synthesis and Analysis of Biodiversity (CESAB) of the French 
Foundation for Research on Biodiversity (FRB), www.fondationbiodiversite.fr. ND's work was supported by the UK Global Challenges Research Fund (grant number ES/S000623/1).

Open Access This article is licensed under a Creative Commons Attribution 4.0 International License, which permits use, sharing, adaptation, distribution and reproduction in any medium or format, as long as you give appropriate credit to the original author(s) and the source, provide a link to the Creative Commons licence, and indicate if changes were made. The images or other third party material in this article are included in the article's Creative Commons licence, unless indicated otherwise in a credit line to the material. If material is not included in the article's Creative Commons licence and your intended use is not permitted by statutory regulation or exceeds the permitted use, you will need to obtain permission directly from the copyright holder. To view a copy of this licence, visit http://creativecommons.org/licenses/by/4.0/.

\section{References}

Adhikari, S., Kingi, T., \& Ganesh, S. (2014). Incentives for community participation in the governance and management of common property resources: The case of community forest management in Nepal. Forest Policy and Economics, 44, 1-9.

Andersson, K. P., Smith, S. M., Alston, L. J., Duchelle, A. E., Mwangi, E., Larson, A. M., et al. (2018). Wealth and the distribution of benefits from tropical forests: Implications for REDD+. Land Use Policy, 72, 510-522.

Appiah-Opoku, S. (2011). Using protected areas as a tool for biodiversity conservation and ecotourism: A case study of Kakum National Park in Ghana. Society and Natural Resources, 24(5), 500-510.

Asiyanbi, A. (2016). A political ecology of REDD plus: Property rights, militarised protectionism, and carbonised exclusion in Cross River. Geoforum, 77, 146-156.

Ball, A., \& Brancalion, P. (2016). Governance challenges for commercial exploitation of a non-timber forest product by marginalized rural communities. Environmental Conservation, 43(3), 208-220.

Barsimantov, J., Racelis, A., Biedenweg, K., \& DiGiano, M. (2011). When collective action and tenure allocations collide: Outcomes from community forests in Quintana Roo, Mexico and Petén, Guatemala. Land Use Policy, 28(1), 343-352.

Bartkowski, B., Hansjürgens, B., Möckel, S., \& Bartke, S. (2018). Institutional economics of agricultural soil ecosystem services. Sustainability, 10(7), 2447.

Berbés-Blázquez, M., Bunch, M. J., Mulvihill, P. R., Peterson, G. D., \& de Joode, B. V. W. (2017). Understanding how access shapes the transformation of ecosystem services to human well-being with an example from Costa Rica. Ecosystem Services, 28, 320-327.

Bidaud, C., Schreckenberg, K., \& Jones, J. P. (2018). The local costs of biodiversity offsets: Comparing standards, policy and practice. Land Use Policy, 77, 43-50.

Biermann, F., Betsill, M. M., Gupta, J., Kanie, N., Lebel, L., Liverman, D., et al. with contributions from Ken Conca, Leila da Costa Ferreira, Bharat Desai, Simon Tay, and Ruben Zondervan. (2009). Earth System Governance: People, places and the planet. Science and implementation plan of the Earth System Governance Project. Earth System Governance Report 1, IHDP Report 20. Bonn, IHDP: The Earth System Governance Project.

Bluwstein, J., Moyo, F., \& Kicheleri, R. (2016). Austere conservation: Understanding conflicts over resource governance in Tanzanian wildlife management areas. Conservation \& Society, 14, $218-231$.

Bottazzi, P., \& Dao, H. (2013). On the road through the Bolivian Amazon: A multi-level land governance analysis of deforestation. Land Use Policy, 30(1), 137-146.

Broggiato, A., Dedeurwaerdere, T., Batur, F., \& Coolsaet, B. (2015). Access and benefit-sharing and the Nagoya Protocol: The confluence of abiding legal doctrines. In B. Coolsaet, F. Batur, A. Broggiato, J. Pitseys, \& T. Dedeurwaerdere (Eds.), Implementing the Nagoya Protocol. Comparing access and benefit-sharing regimes in Europe (pp. 1-29). Leidon, Boston: Nijhoff Publishers.

Cardona, W. C., de Jong, W., Zuidema, P. A., \& Boot, R. (2014). Diverse local regulatory responses to a new forestry regime in forest communities in the Bolivian Amazon. Land Use Policy, 39, 224-232.

CBD. (2020). Zero draft of the post-2020 global biodiversity framework. CBD/WG2020/2/3, 6th January 2020.

Chechina, M., Neveux, Y., Parkins, J. R., \& Hamann, A. (2018). Balancing conservation and livelihoods: A study of forest-dependent communities in the Philippines. Conservation and Society, 16(4), 420-430. 
Chomba, S., Treue, T., \& Sinclair, F. (2015). The political economy of forest entitlements: Can community based forest management reduce vulnerability at the forest margin? Forest Policy and Economics, 58, 37-46.

Cleaver, F., Franks, T., Maganga, F., \& Hall, K. (2013). Institutions, security, and pastoralism: Exploring the limits of hybridity. African Studies Review, 56(3), 165-189.

Clifton, J. (2013). Compensation, conservation and communities: An analysis of direct payments initiatives within an Indonesian marine protected area. Environmental Conservation, 40(3), 287-295.

de Araujo, L. G., de Castro, F., de Freitas, R. R., de Mattos Vieira, M. A. R., \& Seixas, C. S. (2017). Struggles for inclusive development in small-scale fisheries in Paraty, Southeastern Coast of Brazil. Ocean and Coastal Management, 150, 24-34.

Earth System Governance Project. (2018). Earth System Governance. Science and implementation plan of the Earth System Governance Project. Utrecht: Earth System Governance Project.

Faye, P. (2017). The politics of recognition, and the manufacturing of citizenship and identity in Senegal's decentralised charcoal market. Review of African Political Economy, 44, 151.

Faye, P., \& Ribot, J. (2017). Causes for adaptation: Access to forests, markets and representation in Eastern Senegal. Sustainability, 2017(9), 311.

Fischer, C., Muchapondwa, E., \& Sterner, T. (2011). A bio-economic model of community incentives for wildlife management under CAMPFIRE. Environmental \& Resource Economics, 48(2), 303-319.

Gupta, J. (2015). Normative issues in global environmental governance: Connecting climate change, water and forests. Journal of Agricultural and Environmental Ethics, 28(3), 413-433.

Gupta, J., \& Lebel, L. (2010). Access and allocation in Earth System Governance: Water and climate change compared. International Environmental Agreements: Politics, Law and Economics, 10(4), 377-395.

Gustavsson, M., Lindström, L., Jiddawi, N. S., \& De La Torre-Castro, M. (2014). Procedural and distributive justice in a community-based managed marine protected area in Zanzibar, Tanzania. Marine Policy, 46, 91-100.

He, J., \& Sikor, T. (2015). Notions of justice in payments for ecosystem services: Insights from China's Sloping Land Conversion Program in Yunnan Province. Land Use Policy, 43, 207-216.

He, J., \& Xu, J. (2017). Is there decentralization in North Korea? Evidence and lessons from the sloping land management program 2004-2014. Land Use Policy, 61, 113-125.

Hendrickson, C., \& Corbera, E. (2015). Participation dynamics and institutional change in the Scolel Te carbon forestry project, Chiapas, Mexico. Geoforum, 59, 63-72.

Hochleithner, S. (2017). Beyond contesting limits: Land, access, and resistance at the Virunga National Park. Conservation and Society, 15, 100-110.

Horton, L. R. (2009). Buying up nature: Economic and social impacts of Costa Rica's ecotourism boom. Latin American Perspectives, 36(3), 93-107.

Hunt, C. A., Durham, W. H., Driscoll, L., \& Honey, M. (2015). Can ecotourism deliver real economic, social, and environmental benefits? A study of the Osa Peninsula, Costa Rica. Journal of Sustainable Tourism, 23(3), 339-357.

Ingram, V. (2017). Changing governance arrangements: NTFP value chains in the Congo Basin. International Forestry Review, 19 (Supplement 1), 152-169.

Ingram, V., Ros-Tonen, M. A. F., \& Dietz, T. (2015). A fine mess: Bricolaged forest governance in Cameroon. International Journal of the Commons, 9(1), 41-64.

Lockie, S. (2013). Market instruments, ecosystem services, and property rights: Assumptions and conditions for sustained social and ecological benefits. Land use policy, 31, 90-98.

Kashwan, P. (2013). The politics of rights-based approaches in conservation. Land Use Policy, 31, 613-626.

Kopnina, H. (2016). Commodification of natural resources and forest ecosystem services: Examining implications for forest protection. Environmental Conservation, 44(1), 24-33.

Kubitza, C., Krishna, V. V., Urban, K., Alamsyah, Z., \& Qaim, M. (2018). Land property rights, agricultural intensification, and deforestation in Indonesia. Ecological economics, 147, 312-321.

Lammers, P. L., Richter, T., Lux, M., Ratsimbazafy, J., \& Mantilla-Contreras, J. (2017). The challenges of community-based conservation in developing countries-A case study from Lake Alaotra, Madagascar. Journal for Nature Conservation, 40, 100-112.

Martin, A. (2017). Just conservation: Biodiversity, wellbeing and sustainability. London: Routledge.

Martin, A., McGuire, S., \& Sullivan, S. (2013). Global environmental justice and biodiversity conservation. The Geographical Journal, 179(2), 122-131.

Matarrita-Cascante, D., Brennan, M. A., \& Luloff, A. E. (2010). Community agency and sustainable tourism development: The case of La Fortuna, Costa Rica. Journal of Sustainable Tourism, 18(6), 735-756.

Mbaiwa, J. E., Stronza, A., \& Kreuter, U. (2011). From collaboration to conservation: insights from the Okavango Delta, Botswana. Society and Natural Resources, 24(4), 400-411. 
Miller, T. R., Minteer, B. A., \& Malan, L.-C. (2011). The new conservation debate: The view from practical ethics. Biological Conservation, 144, 948-957.

Montoya, M., \& Young, K. R. (2013). Sustainability of natural resource use for an Amazonian indigenous group. Regional Environmental Change, 13(6), 1273-1286.

Mordi, R. (1991). Public Attitudes Towards Wildlife in Botswana. New York, Garland Publishing.

Moscoe, L. J., \& Emshwiller, E. (2016). Farmer perspectives on OCA (Oxalis tuberosa; Oxalidaceae) diversity conservation: Values and threats. Journal of Ethnobiology, 36(2), 235-257.

Moyo, F., Funk, S., \& Pretzsch, J. (2017). Between policy intent and practice: Negotiating access to land and other resources in Tanzania's wildlife management areas. Tropical Conservation Science, 10, 1940082917744167.

Myers, R., \& Hansen, C. P. (2020). Revisiting a theory of access: A review. Society \& Natural Resources, $33(2), 146-166$.

Øian, H., \& Skogen, K. (2016). Property and possession: Hunting tourism and the morality of landownership in rural Norway. Society \& Natural Resources, 29(1), 104-118.

Orchard, S. E., Stringer, L. C., \& Quinn, C. H. (2016). Mangrove system dynamics in Southeast Asia: Linking livelihoods and ecosystem services in Vietnam. Regional Environmental Change, 16, 865-879.

Parker, P., Thapa, B., \& Jacob, A. (2015). Decentralizing conservation and diversifying livelihoods within Kanchenjunga Conservation Area, Nepal. Journal of Environmental Management, 164, 96-103.

Pasgaard, M. (2013). The challenge of assessing social dimensions of avoided deforestation: Examples from Cambodia. Environmental Impact Assessment Review, 38, 64-72.

Pelletier, J., Horning, N., Laporte, N., Samndong, R. A., \& Goetz, S. (2018). Anticipating social equity impacts in REDD+ policy design: An example from the Democratic Republic of Congo. Land Use Policy, 75, 102-115.

Pinyopusarerk, K., \& Tran, T. T. H. (2014). Making community forest management work in northern Vietnam by pioneering participatory action. Land Use Policy, 38, 257-263.

Ribot, J. C., \& Peluso, N. L. (2003). A theory of access. Rural Sociology, 68(2), 153-181.

Robinson, J. G. (2011). Ethical pluralism, pragmatism, and sustainability in conservation practice. Biological Conservation, 144, 958-965.

Roy, A. K. D., Alam, K., \& Gow, J. (2013). Community perceptions of state forest ownership and management: A case study of the Sundarbans Mangrove Forest in Bangladesh. Journal of Environmental Management, 117, 141-149.

Saito-Jensen, M., Sikor, T., Kurniawan, Y., Eilenberg, M., Setyawan, E. P., \& Kustini, S. J. (2015). Policy options for effective REDD+ implementation in Indonesia: The significance of forest tenure reform. International Forestry Review, 17(1), 86-97.

Saeed, A. R., McDermott, C., \& Boyd, E. (2018). Examining equity in Ghana's national REDD+ process. Forest policy and economics, 90, 48-58.

Sandbrook, C., \& Adams, W. M. (2012). Accessing the impenetrable: The nature and distribution of tourism benefits at a Ugandan National Park. Society \& Natural Resources, 25(9), 915-932.

Schlager, E., \& Ostrom, E. (1992). Property-rights regimes and natural resources: A conceptual analysis. Land Economics, 68(3) 249-262.

Schroeder, R. A. (2008). Environmental justice and the market: The politics of sharing wildlife revenues in Tanzania. Society and Natural Resources, 21(7), 583-596.

Sowman, M., \& Sunde, J. (2018). Social impacts of marine protected areas in South Africa on coastal fishing communities. Ocean and Coastal Management, 157, 168-179.

Suiseeya, K. R. M. (2014). Negotiating the Nagoya protocol: Indigenous demands for justice. Global Environmental Politics, 14(3), 102-124.

Suma, T. R., \& Großmann, K. (2017). Exclusions in inclusive programs: State-sponsored sustainable development initiatives amongst the Kurichya in Kerala, India. Agriculture and human values, 34(4), 995-1006.

Thorkildsen, K. (2016). Justice in an unequal relationship? Negotiations between the Quilombo Bombas and the Upper Ribeira State Touristic Park, Brazil. Society \& Natural Resources, 29, 1.

Torpey-Saboe, N., Andersson, K., Mwangi, E., Persha, L., Salk, C., \& Wright, G. (2015). benefit sharing among local resource users: The role of property rights. World Development, 72, 408-418.

Tysiachniouk, M., \& McDermott, C. L. (2016). Certification with Russian characteristics: Implications for social and environmental equity. Forest Policy and Economics, 62(C), 43-53.

Van Wyk, E., Breen, C., \& Freimund, W. (2014). Meanings and robustness: Propositions for enhancing benefit sharing in social-ecological systems. International Journal of the Commons, 8(2), 576-594.

Zafra-Calvo, N., Pascual, U., Brockington, D., Coolsaet, B., Cortes-Vazquez, J. A., Gross-Camp, N., Palomo, I., \& Burgess, N. D. (2017). Towards an indicator system to assess equitable management in protected areas. Biological Conservation, 211, 134-141. 
Publisher's Note Springer Nature remains neutral with regard to jurisdictional claims in published maps and institutional affiliations. 